\title{
Using law enforcement data in trafficking research
}

\section{Authors and affiliations:}

$1^{\text {st }}$ author: Ella Cockbain, Department of Security and Crime Science, University College London (UCL), London, UK e.cockbain@ucl.ac.uk

2nd author: Kate Bowers, Department of Security and Crime Science, UCL, London, UK

Kate.bowers@ucl.ac.uk

$3^{\text {rd }}$ author: Liam Vernon, Modern Slavery and Human Trafficking Unit, National Crime Agency, London, UK liam.vernon@nca.x.gsi.gov.uk

\section{Keywords}

Human trafficking; Modern Slavery; Evidence-based policy; Evidence-based policing; Crime prevention; Labour trafficking; Sex trafficking; Domestic servitude; Child sexual exploitation; Forced labour; Labour exploitation; Trafficking data; Trafficking research methods; Law enforcement data; Trafficking investigations; Trafficking prosecutions.

\section{Abstract}

Law enforcement data are a promising and largely untapped resource for academic research into human trafficking. Better use of such data can help inform and expand an evidence-based approach to counter-trafficking policy and practice. Authored by both academics and a senior law enforcement practitioner, this chapter provides rare and important insights into the theoretical, practical, legal and ethical considerations around using law enforcement data in human trafficking research. Its discussions should prove useful to researchers, practitioners and policy-makers interested in 
understanding and tackling human trafficking more effectively. The chapter begins with a critical appraisal of the human trafficking literature, highlighting particular gaps, imbalances and weaknesses. The stage is then set to explore the utility and applications of a long-neglected but empirically-rich source of data on human trafficking: those that law enforcement agencies generate and/or hold. The limitations of law enforcement data are made explicit and their benefits are explored, with reference to relevant human trafficking studies and innovative research into other crimes. Key considerations are addressed around the actual process of using law enforcement data, drawing on the authors' experiences as researchers and a research-enabler. This section is informed in particular by four recent human trafficking studies in which the authors were involved, all of which used sensitive and hard-to-access law enforcement data. These innovative studies spanned both small- and large-scale datasets, qualitative, quantitative and mixed-method enquiries, internal and international trafficking movements and some of the main variants of human trafficking: sex trafficking, trafficking for domestic servitude and labour trafficking across diverse licit and illicit labour markets.

\section{The trafficking evidence base: weak designs, hard-to-access data and skews in}

\section{focus}

Human trafficking research, data and statistics often have a bad reputation. Despite considerable investment in legislation, policy-making and interventions to counter trafficking, the research base remains notoriously scant (see, e.g., (Cockbain et al. 2018; Efrat 2016; Farrell 2014; Goodey 2008; Van Der Laan et al. 2011)). The trafficking literature is fragmented and underdeveloped: among the numerous criticisms are the predominance of weak research designs, poor-quality data, insufficient methodological clarity, questionable assumptions, emotive or politicised rhetoric, ill-founded inferences and conclusions not properly grounded in the findings (Andrees and van der Linden 2005; Aronowitz 2001; Aronowitz 2009; Cockbain et al. 2018; Di Nicola 2007; Feingold 2010; Goodey 2008; 
Kelly 2002; Kelly 2005; Laczko and Gozdziak 2005; Lehti and Aromaa 2006; Tyldum 2010; Tyldum and Brunovskis 2005). There are also thematic skews, whereby the dominant focus is on victims, international movements and sexual exploitation: offenders, internal (domestic) trafficking and other exploitation types (e.g. labour or domestic servitude) are comparatively neglected (Andrees and van der Linden 2005; Kleemans 2011; Laczko and Gozdziak 2005; Winterdyk and Reichel 2010).

Such criticisms obviously do not mean there is no good research on trafficking but rather that robust, rigorous and high-quality empirical studies are the exception rather than the rule. Many of the general shortcomings in the literature could be addressed through concerted efforts to improve the basic standards of how trafficking research is designed, conducted and reported (Cockbain et al. 2018). Yet, data access remains a more fundamental barrier to the development of the knowledge base.

Research data can take two forms: primary (new data generated specifically for the study in question) or secondary (existing data collected for other reasons). Primary data are used heavily in trafficking research but overwhelmingly in one particular format: qualitative research interviews. With some key exceptions (e.g. (Oram et al. 2012; TNS OBOP and the British Embassy Warsaw 2010; Turner-Moss et al. 2014; Zimmerman et al. 2006)), there is limited evidence of other approaches to primary data collection, such as experiments, surveys or evaluations. Qualitative research interviews have some clear strengths, including the ability to unpick different perspectives on complex issues in a nuanced and context-sensitive manner. They have limitations too, though, such as the costliness of generating data, difficulties accessing relevant participants and reliance on convenience samples. The resultant studies tend to be small-scale, localised and purely exploratory or descriptive: such designs simply do not support more explanatory, hypothesis-driven research or generalisation to other contexts. 
There are also many large-scale, top-down analyses that employ secondary data to address questions around the 'scale', 'costs' and 'nature' of human trafficking, for example. Yet, such publications are often more promising in theory than in reality. Here, the knowledge production process is dominated by official agencies who are the 'owners' of these large-scale datasets, who may not have the necessary interest in, training, skills or capacity for rigorous, sophisticated research (see, e.g., (Cockbain et al. 2018)). Outputs from such agencies rarely go further than presenting basic statistics, generally in the aggregate form: raw individual- or incident-level data are rarely made publically available for use by independent researchers. The validity and utility of various statistics generated by top-down enquiries into trafficking have repeatedly been called into question (Feingold 2010; Goodey 2008; Gozdziak and Collett 2005; Kelly 2002; Kelly 2005; Laczko 2005; Laczko and Gramegna 2003; Tyldum 2010; Tyldum and Brunovskis 2005)). Nevertheless, statistics of dubious provenance are widely and uncritically reported and repeated, leading to the risk that inaccurate information might undermine responses (Tyldum and Brunovskis 2005).

Although long underexploited by academic researchers, secondary data on trafficking have considerable and largely untapped potential to expand, diversify and strengthen the trafficking evidence base. This chapter deals with one particularly promising and often neglected source of secondary data: data generated and/or held by law enforcement agencies (hereafter 'law enforcement data'). Please note that law enforcement is a broad term, encompassing regional and national police forces, specialist agencies, prosecutors, the courts, international police organisations, private security contractors and many more.

Although undoubtedly still marginal, recent years have seen an expansion in academic trafficking research that has used law enforcement data (Brayley et al. 2011; Campana 2016; Cockbain 2018; Cockbain et al. 2011; Cockbain and Brayley-Morris 2017; Cockbain and Wortley 2015; Denton 2016; 
Farrell et al. 2012; Farrell et al. 2014; Farrell and Pfeffer 2014; Gadd et al. 2017; Gavra and Tudor 2015; Kleemans 2015; Kragten-Heerdink et al. 2017; Mancuso 2014; Savona et al. 2014; Tamas et al. 2013). The specific sources employed in such studies have included intelligence logs and enquiries, arrest warrants, detailed investigative case files, legal databases, indictments and other court case files.

Of course, human trafficking is not just a crime and criminal justice issue. It is a complex social phenomenon that has many dimensions including public health, economics, human geography, history, politics and international relations. Just as law enforcement agencies cannot tackle trafficking alone, so too their data are just part of a wider puzzle - albeit an important part.

\section{Limitations of law enforcement data}

Before proceeding, the limitations of law enforcement data should be made clear. First, such data by definition exclude the 'dark figure' of crime: offences, offenders and victims that are not captured in official records. The dark figure of human trafficking may be particularly pronounced, since it is a clandestine activity that plays out on the margins of society. Additionally, even those victims who selfidentify as such may be unwilling to report trafficking for reasons such as: social or physical isolation; psychological or physical confinement; fear or mistrust of authorities; language barriers; threats or violence; fear of recriminations against themselves or their families; worries over their immigration status; and/or their own involvement in stigmatised or criminal activity (Aronowitz 2009; Cockbain 2018; Cockbain and Brayley-Morris 2017; Farrell and Pfeffer 2014; Helfferich et al. 2011; Hopper and Hidalgo 2006; Laczko 2005; Raymond and Hughes 2001). Using a method known as Multiple Systems Estimation (capture-recapture), Silverman (2014) estimated the dark figure of trafficking in the UK to be around 7,000-10,000 victims in 2013, compared with 2,744 known to the authorities. 
Second, law enforcement data may be subject to institutional bias (Andrees and van der Linden 2005; Tyldum and Brunovskis 2005), in the sense that cases that come to the authorities' attention and are officially recorded may differ from those that do not. For example, victims who have certain demographic characteristics or who are exploited in certain sectors may be systematically less likely to be identified by the authorities. Institutional bias is important since it can affect the generalisabiilty of findings but it can be hard to establish the extent and nature of such bias in law enforcement (and other) samples. The reason why is that many of those groups most relevant to trafficking research (targets, victims, offenders, facilitators, consumers of trafficked labour etc) constitute what are known as 'hidden populations' (Tyldum and Brunovskis 2005): groups for which the size, boundaries and characteristics are unknown. Consequently, there is rarely a clear baseline against which to compare official data.

Third, law enforcement data are not a perfect mirror of crime problems or law enforcement responses but rather socially constructed datasets. They are shaped by criminal justice agencies' goals, processes, pressures and norms and are susceptible to human error and other biases (Bjelland and Dahl 2017; Maxfield and Babbie 2011; Noaks and Wincup 2004). In addition, trafficking seems to be something that is largely found when actively sought: law enforcement statistics may therefore be especially sensitive to fluctuations in, for example, awareness, skills, capacity, funding and prioritisation (Aronowitz 2009; Cockbain 2018; Dandurand 2017; International Organization for Migration 2001; Kelly 2002; Kragten-Heerdink et al. 2017; Laczko and Gramegna 2003).

These limitations are consequential and should be borne in mind when framing, designing, conducting and interpreting research. Nevertheless, they are not grounds in themselves to rule out this important source of empirical data on trafficking. Of course, there will always be those that dismiss any academic 
researchers who dirty their hands with law enforcement data as 'administrative criminologists' - i.e. the authorities' lackeys. Such attitudes are naïve, reductionist and myopic and belie a poor grasp of how useful law enforcement data can be in informing crime analysis and intervention (for more on this contentious topic, see (Mayhew 2016)). When conducting virtually any research involving external agencies - be it as a research commissioner, data provider, collaborator and so forth academics ought to make conscious efforts to maintain their independence and intellectual integrity. The same principle of course holds true when working with law enforcement and their data and this theme will be explored further in subsequent sections.

\section{Law enforcement data: a goldmine for trafficking research}

This section engages with the benefits of using law enforcement data in trafficking research: such data have considerable and underexploited potential to inform diverse empirical studies. First, there can be a whole host of practical and ethical advantages to using pre-existing data. From a practical perspective, working with secondary data can avoid duplicating data collection efforts, reduce the costs involved, sometimes (but not always) speed up the research process and increase the reach, thereby enabling large-scale studies of hard-to-reach groups. From an ethical perspective, using 'unobtrusive methods' (Webb et al. 1966) where possible and appropriate can reduce reliance on vulnerable groups (e.g. victims and offenders) and minimise the risk of side effects such as inconvenience, disruption, participation-related distress (Legerski and Bunnell 2010) and 'research fatigue' (Clark 2008; De Angelis 2012).

Second, such data are often unparalleled in the information they contain about offenders and the crime commission process. These data can be particularly relevant to situational type research, i.e. enquiries that focus on the 'who', 'what', 'where', 'when' and 'how' of crime, rather than the 'why'. These data are also invaluable in helping redress one of the most longstanding and pronounced skews 
in the trafficking literature: the comparative neglect of offenders and offending (Kleemans 2011; Laczko and Gozdziak 2005; Parmentier 2010).

Third, law enforcement data can support large-scale quantitative analyses. There is a particularly pronounced gap in the trafficking literature around high-quality, rigorous statistical analyses of trafficking issues using larger datasets (Andrees and van der Linden 2005; Cockbain et al. 2018; Tyldum and Brunovskis 2005). Law enforcement records are one obvious source of data for more sophisticated quantitative research, which could greatly advance the evidence base on trafficking. Research using inferential statistics, for example, has much to offer in helping tease out the relationships between variables and explain patterns observed in the data. Although many official publications include statistics on trafficking, these are typically (and understandably) administrative summaries as opposed to scientific research (Cockbain et al. 2018). For example, they tend to report on a series of variables at aggregate level (e.g. total number of victims of a given gender, age group, country of origin etc.) without considering the possible interplay between these variables. To date, there have been just a handful of academic studies that have used law enforcement data to scrutinise the distribution and characteristics of trafficking cases at local or national level (Denton 2016; Farrell et al. 2012; Gadd et al. 2017; Kragten-Heerdink et al. 2017; Tamas et al. 2013).

Fourth, law enforcement data can support detailed, bottom-up analyses of particular trafficking problems. Such micro-level, empirical enquiries are a vital counterbalance to large-scale studies. Trafficking is a process crime rather than a one-off criminal event and its distribution across numerous locations, times and people can create analytical challenges. As with other complex and organised crimes (Bullock et al. 2010), many trafficking-related research questions may be better addressed through analysis of detailed investigative case files than aggregate crime records. Notably, most of the limited academic research on trafficking that uses law enforcement data has been at the 
micro-level. Such work has favoured a case-study based approach to exploring areas like business models, the crime commission process and the structure of victim and offender networks (Brayley et al. 2011; Campana 2016; Cockbain 2018; Cockbain et al. 2011; Cockbain and Brayley-Morris 2017; Cockbain and Wortley 2015; Gavra and Tudor 2015; Jokinen et al. 2013; Kleemans 2015; Mancuso 2014; Savona et al. 2014). Through the careful, nuanced examination of empirical data, such studies have helped to expose common myths and stereotypes about trafficking.

Fifth, law enforcement data are invaluable for research into criminal justice practices and their effectiveness (Bjelland and Dahl 2017). The typical application of law enforcement data thus far has been to understanding trafficking problems, leaving responses comparatively neglected. The most obvious exception here is research in the United States into the challenges of investigating and prosecuting trafficking (Farrell et al. 2012; Farrell et al. 2014; Farrell and Pfeffer 2014). Despite heavy investment in counter-trafficking, there are strikingly few evaluations of interventions (Cockbain et al. 2018; Van Der Laan et al. 2011). Secondary law enforcement data are a valuable source for evaluations of what is effective in preventing trafficking, protecting victims and pursuing traffickers. Since trafficking is a complex, real-world problem, it can be helpful here to think not just in terms of 'what works?' but how it works and under what conditions it does and does not work (for more, see (Johnson et al. 2015; Kennedy 2015; Pawson and Tilley 1997; Tilley 2006)).

\section{Considerations when using law enforcement data}

This section deals with considerations when using law enforcement data. It is written specifically within the context of human trafficking research and focuses firmly on the research process, rather than research methods. There is little prior research on which to draw here: in line with the conventions of social science scholarship, published studies tend to present a stylised, sanitised 
account that downplay or overlook issues encountered along the way (Kennedy 2015). Yet, understanding, anticipating and responding to the messy realities of the research process is vital to the success of such research - and even to whether it happens in the first place. This section draws on the authors' own experiences either as academics (first and second authors) or as a research enabler and data provider within law enforcement (third author). It is particularly informed by experiences across four recent trafficking studies, the key characteristics of which are summarised in Table 1. The National Crime Agency (the organisation to which the third author belongs) was a data provider in two of the studies (case studies A and B) and a research enabler in the other two (case studies C and D), helping identify relevant cases for inclusion and facilitating introductions to relevant police personnel. The considerations raised here are not intended as an exhaustive or prescriptive list but simply a selection of issues that may well prove useful and relevant to future researchers and their law enforcement collaborators. 
Table 1: Overview of trafficking research case studies (Please note the summary only covers those aspects of the project relating to secondary law enforcement data. Some projects had additional components that are not covered here).

\begin{tabular}{|c|c|c|c|c|c|c|c|}
\hline $\begin{array}{l}\text { Case } \\
\text { study }\end{array}$ & $\begin{array}{l}\text { Research } \\
\text { question(s) }\end{array}$ & Datasets & $\begin{array}{l}\text { Data } \\
\text { provider(s) }\end{array}$ & Method(s) & $\begin{array}{l}\text { Key } \\
\text { publicatio } \\
\mathrm{n}(\mathrm{s})\end{array}$ & Key findings & Implications and applications \\
\hline A & $\begin{array}{l}\text { Can the } \\
\text { characteristic } \\
\text { s of } \\
\text { trafficking } \\
\text { cases reliably } \\
\text { predict } \\
\text { exploitation } \\
\text { type: sexual } \\
\text { exploitation, } \\
\text { domestic } \\
\text { servitude or } \\
\text { other labour? }\end{array}$ & $\begin{array}{l}\text { Anonymised victim database } \\
\text { from the UK's National } \\
\text { Referral Mechanism (NRM). } \\
\text { Dataset contains topline data } \\
\text { on } 6,858 \text { suspected victims } \\
\text { identified to the authorities } \\
2009-2014 \text {, of whom around } \\
40 \% \text { were officially assessed } \\
\text { as having been trafficked. }\end{array}$ & $\begin{array}{l}\text { National } \\
\text { Crime Agency }\end{array}$ & $\begin{array}{l}\text { Logistic regression } \\
\text { analysis, with } \\
\text { exploitation type } \\
\text { as outcome } \\
\text { variable and case } \\
\text { characteristics as } \\
\text { independent } \\
\text { variables. }\end{array}$ & $\begin{array}{l}\text { Paper by } \\
\text { Cockbain } \\
\text { and } \\
\text { Bowers in } \\
\text { preparatio } \\
\text { n }\end{array}$ & $\begin{array}{l}\text { Variables such as } \\
\text { victims' gender, age, } \\
\text { region of origin, source } \\
\text { of referral and region of } \\
\text { identification were } \\
\text { significant predictors of } \\
\text { trafficking type. The } \\
\text { overall models (sex vs. } \\
\text { labour and labour vs. } \\
\text { domestic servitude) } \\
\text { were not only } \\
\text { significant but had a } \\
\text { good fit, explaining } \\
\text { much of the variance in } \\
\text { the data. }\end{array}$ & $\begin{array}{l}\text { The results highlight the need for a } \\
\text { more nuanced approach to analysis } \\
\text { and intervention that is sensitive to } \\
\text { variation between trafficking types } \\
\text { and regions. A one-size-fits-all } \\
\text { approach historically developed } \\
\text { around sex trafficking is unlikely to } \\
\text { be effective. } \\
\text { The limitations of the current } \\
\text { database identified through the } \\
\text { analysis (e.g. missing data, } \\
\text { ambiguous categorisation, clustering } \\
\text { of cases) have been highlighted and } \\
\text { fed into the Home Office's review } \\
\text { and restructuring of the NRM. They } \\
\text { have also helped inform the } \\
\text { development of National Policing's } \\
\text { new data tool on human trafficking } \\
\text { and modern slavery. The intention in } \\
\text { doing so is to help maximise the } \\
\text { robustness, validity and utility of } \\
\text { these systems, supporting a better } \\
\text { evidence base on trafficking in the } \\
\text { UK. }\end{array}$ \\
\hline B & $\begin{array}{l}\text { What is the } \\
\text { geospatial } \\
\text { distribution } \\
\text { of labour } \\
\text { trafficking } \\
\text { cases } \\
\text { affecting the } \\
\text { UK and } \\
\text { involving } \\
\text { European } \\
\text { victims?; }\end{array}$ & $\begin{array}{l}\text { Detailed case files for } 453 \\
\text { victims of labour trafficking } \\
\text { in the UK in } 2012 \text { and } 2013 . \\
\text { The sample comprised the } \\
\text { full set of officially } \\
\text { recognised labour trafficking } \\
\text { victims who came from the } \\
\text { European Economic Area } \\
\text { (EEA) and were trafficked to, } \\
\text { within and/or from the UK: } \\
\text { together they accounted for }\end{array}$ & $\begin{array}{l}\text { National } \\
\text { Crime Agency }\end{array}$ & $\begin{array}{l}\text { Geographical } \\
\text { information } \\
\text { systems (GIS) } \\
\text { techniques for } \\
\text { retrospective } \\
\text { mapping of } \\
\text { distribution of } \\
\text { trafficking } \\
\text { locations. } \\
\text { Descriptive } \\
\text { statistical analyses }\end{array}$ & $\begin{array}{l}\text { Research } \\
\text { by } \\
\text { Cockbain } \\
\text { and } \\
\text { Bowers } \\
\text { still on- } \\
\text { going }\end{array}$ & $\begin{array}{l}\text { Research still } \\
\text { underway but } \\
\text { preliminary findings } \\
\text { include that: a wide } \\
\text { range of industries } \\
\text { affected (both licit and } \\
\text { illicit); large proportion } \\
\text { of victims exploited } \\
\text { across multiple sectors; } \\
\text { victims and offenders } \\
\text { typically the same }\end{array}$ & $\begin{array}{l}\text { Preliminary results highlight the } \\
\text { diversity and complexity of labour } \\
\text { trafficking: it is not a homogenous } \\
\text { issue and interventions may need to } \\
\text { be targeted accordingly. Various } \\
\text { findings have obvious implications } \\
\text { for the Home Office's restructuring of } \\
\text { the NRM and development of the } \\
\text { National Policing data tool that have } \\
\text { been fed in accordingly, e.g. the need } \\
\text { for improved data collection around }\end{array}$ \\
\hline
\end{tabular}




\begin{tabular}{|c|c|c|c|c|c|c|c|}
\hline & $\begin{array}{l}\text { What are the } \\
\text { characteristic } \\
\text { s of the } \\
\text { victims, } \\
\text { offenders and } \\
\text { crime } \\
\text { commission } \\
\text { process? }\end{array}$ & $\begin{array}{l}\text { about } 80 \% \text { of overall } \\
\text { confirmed labour trafficking } \\
\text { cases in the UK over this } \\
\text { period (access to the } \\
\text { remaining } 20 \% \text { of cases - } \\
\text { non-EEA cases held by UK } \\
\text { Visas and Immigration -was } \\
\text { sought but not granted). }\end{array}$ & & $\begin{array}{l}\text { of various } \\
\text { characteristics of } \\
\text { the individuals, } \\
\text { places and } \\
\text { processes } \\
\text { involved, with } \\
\text { inferential } \\
\text { analyses as } \\
\text { appropriate. } \\
\text { Prospective crime } \\
\text { mapping too if } \\
\text { time and data } \\
\text { permit. }\end{array}$ & & $\begin{array}{l}\text { nationality; apparent } \\
\text { concentration of } \\
\text { particular demographic } \\
\text { groups in particular } \\
\text { regions and industries, } \\
\text { possibly reflecting } \\
\text { general distribution of } \\
\text { these diasporas; } \\
\text { apparent preference for } \\
\text { adult and male victims; } \\
\text { apparent } \\
\text { overrepresentation of } \\
\text { Roma offenders (and } \\
\text { victims?); victims } \\
\text { overwhelmingly } \\
\text { recruited via deception } \\
\text { rather than coercion or } \\
\text { abduction; victims } \\
\text { typically entered the } \\
\text { UK willingly and } \\
\text { through legal channels; } \\
\text { physical confinement of } \\
\text { victims rare, with } \\
\text { control mechanisms } \\
\text { more commonly } \\
\text { including promises, } \\
\text { threats, violence, social } \\
\text { isolation and economic } \\
\text { manipulation; } \\
\text { numerous and } \\
\text { substantial barriers to } \\
\text { intervention identified. }\end{array}$ & $\begin{array}{l}\text { victim ethnicity and geographical } \\
\text { locations to help support finer } \\
\text { targeting of prevention, disruption, } \\
\text { detection etc. The tendency to enter } \\
\text { the UK legally and willingly raises } \\
\text { questions about the efficacy of } \\
\text { interventions at border when dealing } \\
\text { with EU victims. The various } \\
\text { preliminary results have been used } \\
\text { to inform training for national and } \\
\text { international law enforcement } \\
\text { agencies (e.g. CEPOL) around labour } \\
\text { trafficking. This study has generated } \\
\text { substantial interest among national } \\
\text { and international stakeholders and } \\
\text { further findings expected to be } \\
\text { impactful. }\end{array}$ \\
\hline $\mathrm{C}$ & $\begin{array}{l}\text { What } \\
\text { situational } \\
\text { factors and } \\
\text { processes } \\
\text { contribute to } \\
\text { the } \\
\text { trafficking of } \\
\text { British } \\
\text { children } \\
\text { within the UK } \\
\text { for sexual }\end{array}$ & $\begin{array}{l}\text { Extensive investigative case } \\
\text { files (including transcripts of } \\
\text { interviews with victims and } \\
\text { suspects, results of digital } \\
\text { forensic analyses, case } \\
\text { summaries and criminal } \\
\text { records) and court records } \\
\text { from six of the earliest and } \\
\text { largest investigations of this } \\
\text { nature. The six cases } \\
\text { together featured } 55\end{array}$ & $\begin{array}{l}\text { Five police } \\
\text { forces and } \\
\text { Her Majesty's } \\
\text { Courts and } \\
\text { Tribunal } \\
\text { Service. }\end{array}$ & $\begin{array}{l}\text { Case-study based } \\
\text { design with a } \\
\text { mixed-methods } \\
\text { approach. Specific } \\
\text { methods included } \\
\text { social network } \\
\text { analysis and both } \\
\text { qualitative and } \\
\text { quantitative } \\
\text { content analysis. }\end{array}$ & $\begin{array}{l}\text { Cockbain } \\
(2018) ; \\
\text { Cockbain } \\
\text { and } \\
\text { Wortley } \\
(2015) ; \\
\text { Cockbain } \\
\text { (2013b) }\end{array}$ & $\begin{array}{l}\text { There were remarkable } \\
\text { similarities between } \\
\text { and within the six } \\
\text { cases. This was a } \\
\text { complex crime } \\
\text { involving sprawling } \\
\text { networks of victims and } \\
\text { offenders and } \\
\text { extending well beyond } \\
\text { the core activity } \\
\text { investigated. Victims }\end{array}$ & $\begin{array}{l}\text { The results help debunk myths and } \\
\text { challenge stereotypes, highlighting } \\
\text { for example the fallacy of idealised } \\
\text { constructions of victimhood and } \\
\text { notions of highly organised and } \\
\text { sophisticated gangs. The findings } \\
\text { highlight the need for improved } \\
\text { protection (rather than relying on } \\
\text { reactive enforcement alone) and } \\
\text { emphasise the need for more } \\
\text { collaborative, connected and }\end{array}$ \\
\hline
\end{tabular}




\begin{tabular}{|c|c|c|c|c|c|c|c|}
\hline & $\begin{array}{l}\text { exploitation } \\
\text { and impede } \\
\text { official } \\
\text { responses? }\end{array}$ & $\begin{array}{l}\text { offenders (defendants) and } \\
43 \text { victims (complainants). }\end{array}$ & & & & $\begin{array}{l}\text { had obvious } \\
\text { vulnerabilities but } \\
\text { despite widespread } \\
\text { concerns about their } \\
\text { credibility as witnesses, } \\
\text { eventual conviction } \\
\text { rates were average or } \\
\text { better. The trafficking } \\
\text { appeared largely casual } \\
\text { and opportunistic and } \\
\text { offenders seemed to } \\
\text { operate with a sense of } \\
\text { impunity. Some victims } \\
\text { actively particulated in } \\
\text { recruiting and } \\
\text { grooming their peers } \\
\text { and facilitating abuses. } \\
\text { The trafficking } \\
\text { appeared largely } \\
\text { routinised and heavily } \\
\text { entrenched in everyday } \\
\text { activities and } \\
\text { associations. Overall, } \\
\text { the structures, } \\
\text { processes and } \\
\text { dynamics of both } \\
\text { offender and victim } \\
\text { networks appeared to } \\
\text { promote, provoke, } \\
\text { facilitate, spread and } \\
\text { sustain trafficking } \\
\text { activity and complicate } \\
\text { criminal justice } \\
\text { responses. Taken as a } \\
\text { whole, the results gave } \\
\text { strong grounds to } \\
\text { believe that this form of } \\
\text { trafficking may be } \\
\text { socially contagious. }\end{array}$ & $\begin{array}{l}\text { innovative responses. The possibility } \\
\text { of social contagion bears particular } \\
\text { consideration. Indeed, the work has } \\
\text { helped stimulated network-based } \\
\text { interventions in two police forces in } \\
\text { the UK, designed to identify high-risk } \\
\text { individuals and support early } \\
\text { intervention. Further consideration } \\
\text { is much needed around victim- } \\
\text { offender hybrids and how best to } \\
\text { respond to and protect them and } \\
\text { those they endanger. The research } \\
\text { has also fed into various action plans, } \\
\text { national strategies and reviews. } \\
\text { Finally, the work has supported a } \\
\text { critical, informed counterbalance to } \\
\text { sensationalist accounts of Asian sex } \\
\text { gang predators. }\end{array}$ \\
\hline $\mathrm{D}$ & $\begin{array}{l}\text { How are } \\
\text { victims } \\
\text { trafficked in } \\
\text { the UK's }\end{array}$ & $\begin{array}{l}\text { Investigative case files from } \\
\text { three major investigations, } \\
\text { together involving } 15 \\
\text { offenders (defendants) and }\end{array}$ & $\begin{array}{l}\text { Three police } \\
\text { forces }\end{array}$ & $\begin{array}{l}\text { Case-study based } \\
\text { design, using } \\
\text { primarily } \\
\text { qualitative content }\end{array}$ & $\begin{array}{l}\text { Cockbain } \\
\text { and } \\
\text { Brayley- } \\
\text { Morris }\end{array}$ & $\begin{array}{l}\text { Strong consistencies } \\
\text { within and between the } \\
\text { three cases in terms of } \\
\text { recruitment, }\end{array}$ & $\begin{array}{l}\text { The results challenge stereotypes } \\
\text { around trafficking, its victims and } \\
\text { what 'normal' responses are. They } \\
\text { highlight numerous issues that are }\end{array}$ \\
\hline
\end{tabular}




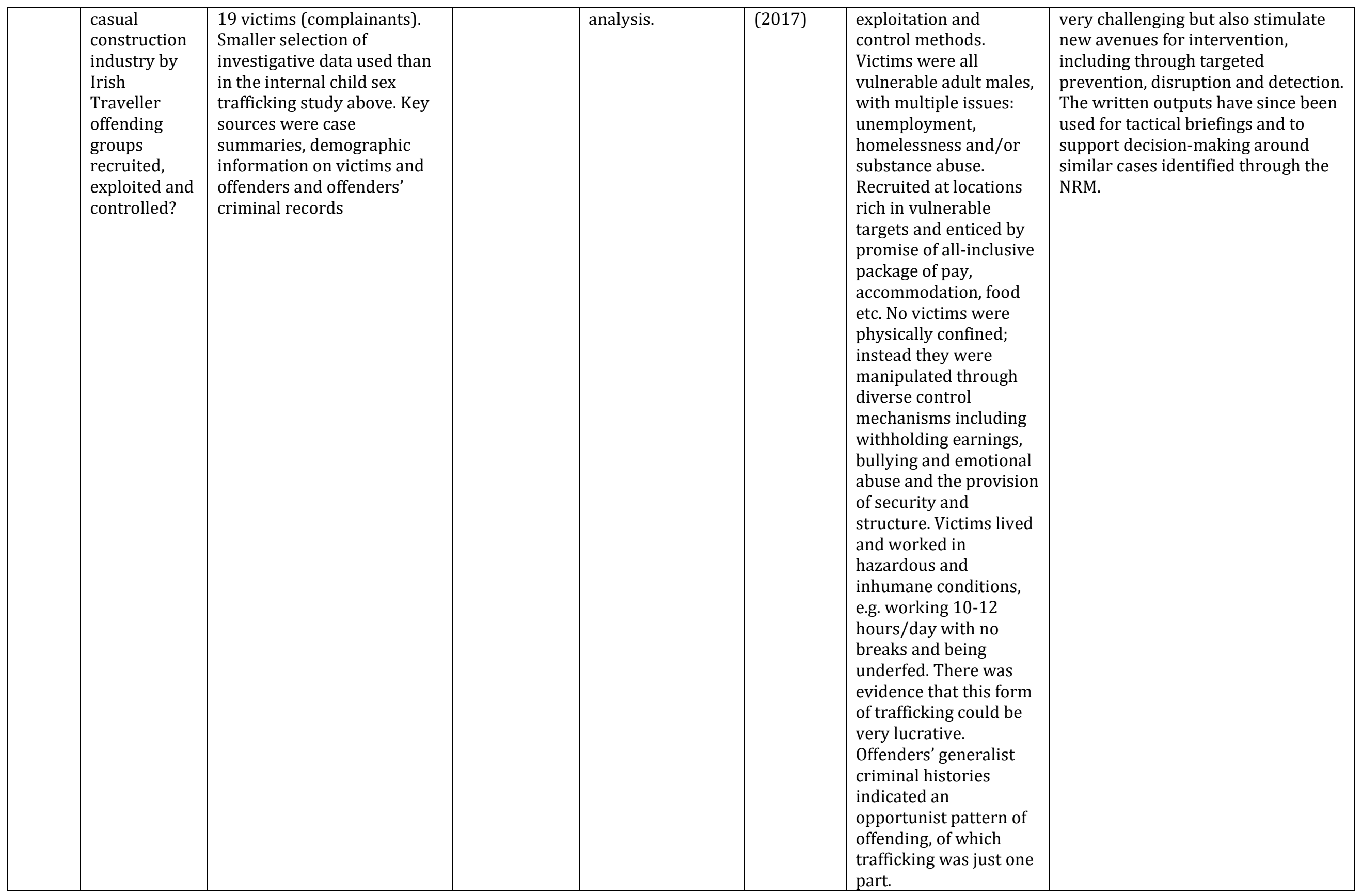




\section{Initial design and contact}

The choice of topic and research question(s) is fundamental to any study. When seeking access to law enforcement data that are not publically available, the chances of success may well be greater if a proposed study addresses an issue seen to be timely, relevant and meeting a gap in the knowledge base. The trouble with trafficking is that the same issue might be perceived by researchers as uncharted territory and by officers as well-understood already, since law enforcement agencies often produce restricted internal analyses, the existence of which can be hard to establish from outside let alone their contents. There are also many aspects of human trafficking that are genuinely poorly-understood but may not be seen as worthy of support, for example because of their limited scale and impacts (perceived or actual).

Identifying law enforcement agencies that could be suitable research enablers, gatekeepers and/or data providers and initiating early contact can help ensure that their views are listened to at the design phase. All the case studies from Table 1 involved early consultation with potential gatekeepers and data providers. The thematic focus of the research in case studies $\mathrm{C}$ and $\mathrm{D}$ was particularly influenced by such consultation: the eventual research responded to a clearly articulated need to expand the evidence base on these particular subsets of trafficking, which were identified as growing priorities but very poorly understood. An appreciation of agencies' time-scales, priorities, resource demands and available data may lead to very valid amendments to initial ideas. Early consultation can help incorporate law enforcement agencies' experiential 
knowledge: a valuable and often overlooked resource. It can also increase a contact or organisation's sense of 'ownership', potentially leading to greater commitment in the long run. Having demonstrable support for a proposal can also be critical to the success of funding applications, as happened with case studies $\mathrm{A}$ and $\mathrm{B}$.

From a researcher's perspective, managing early engagement means striking a careful balance between, on the one hand, pragmatism and flexibility and, on the other, assertiveness and commitment to the work's integrity, intellectual rigour and independence. It is important that outside pressures do not shape the design of a study in a way that could compromise its fundamental aims, the rationale behind it, its methodological robustness and the validity of its findings. The first and second authors have found thus far that many possible tensions or conflicts of interest can be avoided by being candid from the start about one's plans, thinking carefully and critically about all aspects of the design, meticulously and transparently documenting the methods and data (and the decisions and assumptions underpinning them) and generally being open to suggestions without following them slavishly. Where outside agencies are involved in the identification and selection of cases for research, it is particularly vital to have clear, explicit and well-justified inclusion criteria to minimise the potential for selection bias from either side.

Although good contacts to law enforcement agencies are clearly a valuable resource, they are not necessarily critical to using law enforcement data. We found that accessing court-held data in the UK for case study C was relatively 
straightforward, since Her Majesty's Courts and Tribunal Service has a standardised application process in place for researchers. Securing access to data held by police forces or the National Crime Agency has proved more complicated and relied heavily on establishing good contacts and conducting negotiations with each agency on a one-to-one basis: this is likely due at least partially to the fragmentation of the UK policing system.

The National Crime Agency's Modern Slavery and Human Trafficking Unit (previously the UK Human Trafficking Centre) receives many requests for research engagement each year but relatively few have been supported. The reason for this is that it can be challenging and resource-intensive to differentiate between those requests that are of clear practical and strategic value to the agency and those that have little such relevance. To open doors, it can therefore be useful to network broadly and draw upon the support and contacts of colleagues, supervisors and other non-law enforcement agencies. A request that is directed to a named individual (rather than a generic agency address) and comes via a shared acquaintance may be treated more favourably. Introductions to relevant police forces on case studies $\mathrm{C}$ and $\mathrm{D}$ certainly helped smooth the process of data access. The development of formalised networks of academics and agencies interested in trafficking research could help better embed relationships and open up data access opportunities: one such example is the UK Modern Slavery Police Transformation Unit's organisation of a series of academic roundtables designed to promote police relevant research, encourage partnerships and support dissemination. 


\section{Understanding resourcing}

Law enforcement agencies may directly commission academic research, which carries obvious direct costs. Academics completing such commissions may experience particular pressures to conform to certain expectations and requests or find agencies to be resistant to certain findings that are seen as detrimental or otherwise unwanted. Such unfortunate realities have been documented elsewhere in the literature on applied police research (see, e.g., (Cockbain and Knutsson 2015a)) but the first and second authors have thankfully not experienced them in their trafficking research, or at least not thus far.

None of the case studies featured here were directly commissioned and funded by law enforcement agencies. Although they were theoretically 'free', they nevertheless incurred costs to the agencies in terms of resources that could have been used elsewhere: 'opportunity costs'. Examples include time spent by agency staff reading and commenting on proposals or final publications, securing internal approvals, completing data-sharing agreements, locating and extracting data, arranging access to buildings, computer systems etc., providing background information or answering questions. There may also be tangible direct costs, such as those associated with vetting researchers.

Researchers may not be aware from the outset of the processes and procedures it can take to secure approval for support within a law enforcement agency. Even granting a seemingly simple request might require a whole host of legal and bureaucratic obstacles to first be cleared. Where a project is grander in ambition and requires access to extensive sensitive data, law enforcement co-operation 
can entail a significant medium-term commitment. During the data collection phase for case study B, for example, the first author spent several months inside the National Crime Agency going through thousands of pages of original files to extract the necessary data.

Negotiating data access can also be very resource-intensive for researchers, involving numerous phone calls, emails and visits and considerable time spent arranging and waiting for ethical approvals, legal agreements governing data sharing and security clearance. Data collection and analysis may then involve further costs associated with extracting information in situ (e.g. accommodation costs if a secure site in question is outside commuting distance) or simply due to the time needed to process the data. In case study $\mathrm{C}$, for example, the investigative case files were extensive and empirically-rich but also very lengthy: with each case numbering 4,000-6,000 pages of documentation and six such cases to process, a large proportion of the grant time went into processing raw data and extracting relevant information. Even dealing with much more concise data, such as the database of suspected victims in case study A, can involve more resources than expected. Using administrative data not collected for research purposes meant much time had to be spent on pre-processing the data (cleaning, re-coding etc.) to get them in a useable format for analysis and even then the volume of missing data restricted what could be done with them (for further discussion of similar challenges in a different context, see (Cockbain et al. 2016)).

In light of the resourcing challenges discussed here, open dialogue between researchers and law enforcement partners may be helpful in ensuring clarity, 
setting and managing expectations and supporting effective planning and allocation of resources from both sides. Additionally, it might help to spend time identifying possible and likely sources of costs (financial or other) at the design stage and factor them in wherever possible to the research funding and timelines. Depending on the particulars of a given funder and call, it may be possible to offset law enforcement agencies' costs in this manner too, which could help remove economic barriers to supporting research.

\section{Securing organisational support}

To ensure projects requiring law enforcement support and data provision are maximally resilient, it helps to secure buy-in at organisational rather than just individual level. Without organisational support, projects can lose impetus or become derailed if a key contact (in police terms, a 'single point of contact') moves position or leaves the agency. Over the lifetime of case study B, the leadership of the National Crime Agency's trafficking unit has changed multiple times: without organisational support, the project would likely have floundered.

Persuading busy law enforcement agencies to commit to a research project requires the anticipated benefits to outweigh the anticipated costs. While the onus is first and foremost on the academic to communicate the benefits of their proposed research, their law enforcement contacts will then need to persuade other internal stakeholders - and possibly external ones too - to support the work. Part of the challenge there may be making a case for why independent, academic research is needed as opposed to an internal piece of analysis using the 
same data: especially in times of funding cuts, agencies have much to gain from academics' research experience, analytical skills, capacity, independence and fresh perspectives. Being able to identify clear links to policy, strategic or tactical objectives can also help promote a case for support. One unfortunate and largely unavoidable issue relates to long time frames from applications for funding (at which point a provisional commitment may be sought) to the initiation of projects: operational priorities can change rapidly and the enthusiasm for a given project may no longer be there a year later. Of course, the opposite can be true: the increased prioritisation of the issue by the time case study B began meant the researchers were granted access to far more data than had been provisionally agreed.

Among the barriers to overcome in securing support are the off-putting 'ivory towers' stereotypes of academia, perceptions of research as a distraction from 'real policing' and general suspicions of outside researchers (for similar points in different contexts, see (Canter 2004; Fleming 2010; Foster and Bailey 2010; Kennedy 2015; Perez and Shtull 2002; Sheptycki 2004)). The authors have experienced difficulties from the outside (as researchers) and the inside (as a would-be partner) when faced with law enforcement personnel who categorically dismiss research and actively obstruct attempts at collaboration. In their experiences at least, these individuals have fortunately been in the minority and they have dealt with many forward-thinking professionals who recognised the value of research in informing understanding, policy and practice. 
With the growing prioritisation of human trafficking nationally and internationally, law enforcement agencies face increased scrutiny and pressure. Greater participation in research offers law enforcement agencies the opportunity to play a more active role in shaping the research agendum and contributing to the knowledge production process. Growing interest in evidencebased approaches to crime prevention may also stimulate increased opportunities for academic-law enforcement collaborations, especially if more inclusive perspectives are taken on what types of evaluation can generate valid evidence on 'what works' (for more, see, e.g., (Bullock and Tilley 2009; Cockbain and Knutsson 2015b; Kennedy 2015; Sparrow 2011; Tilley 2006)).

\section{Dealing with sensitive and restricted data}

Trafficking is by nature a sensitive topic, involving as it does illegal and taboo activity and vulnerable populations. It is also increasingly politicised, which is something of a double-edged sword: on the one hand, it can add weight to arguments for supporting research projects and make law enforcement agencies more open to collaboration; on the other, it can fuel concerns about the risk of reputational harm associated with sharing data externally. A sudden surge in media attention around so-called 'Asian sex gangs' and associated criticism of police handling of such cases (Cockbain 2013a), for example, made data access negotiations on case study $\mathrm{C}$ harder and more time-consuming.

When working with law enforcement data, it is important to understand and comply with relevant data protection legislation. In the UK, the treatment of 
personal data (data from which an individual may be identified) is currently governed by the Data Protection Act 1998, soon to be superseded by the new European Union (EU) General Data Protection Regulation. It is entirely possible to conduct research using large-scale, aggregate law enforcement datasets that do not contain personal data, as happened in case study A. Nevertheless, most if not all of the datasets used in case studies B, C and D contained sensitive personal data. Although anonymising these data before providing them to the researchers might theoretically have been possible, it would have been hugely expensive given the volume of the data. When dealing with complex cases involving multiple people and places, simply redacting out names severely limits the analytical utility of the data. Alternative approaches, such as recoding geospatial data to a higher level of abstraction or assigning all individuals and places unique identifiers are, however, far more resource-intensive and prone to human error.

There are obvious situations then in which non-anonymised data are preferable or even necessary. It is important therefore to be aware of exemptions under which personal information can be shared. At the time of the case studies, the most relevant exemption was 'the prevention or detection of crime' under the Data Protection Act 1998. Where research can ultimately contribute to countertrafficking and public protection, law enforcement agencies were within their legal rights to share such data. Under the new General Data Protection Regulation, personal data originally collected for a relevant task or function can be further processed for scientific research without first needing to establish a separate lawful basis (Information Commissioner's Office 2018). When using 
personal data from law enforcement sources in research, the people involved (e.g. victims and offenders) would not generally be aware that they are being studied nor would they have they given consent. While this situation is common in crime research, from an ethical perspective it means extra care should be taken to protect unwitting participants' anonymity and confidentiality.

Although academics are generally used to managing ethical review processes (including data protection registration and risk assessments), they may well have less experience working with data that are protectively marked: i.e. subject to official government security markings. In the UK, many law enforcement data on trafficking are protectively marked, meaning that researchers may need to undergo appropriate security clearance and training. The vetting process can be time consuming (several months at a minimum) and should be properly built into the project timelines.

Regardless of whether data are protectively marked or 'just' sensitive, it is vital to appropriate provisions in place for the secure transfer, storage or disposal of data. The authors have previously sought advice on data handling from, among others, university and law enforcement information security and legal departments. Various provisions have then been agreed and executed to protect the data. At University College London (UCL), the opening of a secure research data laboratory has proved valuable for the management of data from the UK labour trafficking project. Accredited by London's Metropolitan Police Service to Police Assured Secure Facility level, this facility opens up new possibilities for the use of sensitive datasets by researchers from UCL and other institutions. 
Securing access to a hard-to-reach dataset on trafficking can offer very exciting and unprecedented opportunities for research. The process from getting provisional agreement to support a project to actually accessing and extracting the necessary research data can be long, convoluted and, at times, rather nervewracking. When the data finally become accessible, the authors have found it is worth prioritising securing those data above virtually any other commitments at the time: what is available today may not be so available in a few months' time.

A final consideration here is that law enforcement data may contain harrowing and distressing material. Researchers' responses and resilience are likely influenced by both individual and environmental factors. They and their host organisations can help by ensuring protective strategies are in place as needed. The first author has found working with large-scale aggregate data sets to be unproblematic in this respect (e.g. case study A), whereas on case studies B and C processing extremely voluminous raw data comprised of individual accounts of abuse proved emotionally, mentally and physically draining at times: not so much because of the unique horrors of any particular incident but the cumulative effect of hundreds upon hundreds of pages of misery. Although luckily such negative effects have been short-lived, this author is now more alert to these issues and would encourage researchers working with such data to identify self-care strategies that work for them and exercise them as needed. 


\section{Managing dissemination}

The final area to consider is the dissemination process. Timelines to dissemination and types of output will vary between research projects. Generally speaking, the academic publication process is not particularly well aligned with the 'need it now' culture of law enforcement. Law enforcement agencies can greatly appreciate the dissemination of findings through other channels, such as restricted internal reports, practitioner-focused conference presentations or training or even informal updates - all of which can be produced ahead of a final academic outputs and may be far better tailored to their needs. All four case studies have involved various outputs of this nature. Such steps can help ensure research is seen as mutually beneficial and not just a one-way process that strains law enforcement resources without giving much back (see also (Cockbain 2015; Madensen and Sousa 2015; Maxfield and Babbie 2014)).

From an academic perspective, peer-reviewed journal articles generally remain the gold standard and it is important for career development to be able to publish in this manner. It is important to minimise the risks that using restricted law enforcement data hinders publication: as with the timelines issue this requires openness, respect and understanding on both sides. The authors' experience on trafficking projects has been very positive in this respect. As a safeguard, however, they now deliberately build an agreed approach to managing the publication process into any data sharing agreements. On case studies A and B, for example, it was agreed that academics would share drafts of formal outputs based on research using restricted data ahead of time and law enforcement data providers in turn have a set period within which to respond. 
This gives them the opportunity to raise concerns around data sensitivity or inadvertent factual errors and request they be addressed: this is not, to be clear, an opportunity to edit unwanted results and thus undermine the integrity of the research.

\section{Summary}

Law enforcement data have considerable and largely unmet potential to improve understanding of and responses to human trafficking. Such data have some key limitations that should be considered in designing, conducting and interpreting research. These limitations are far outweighed by the benefits, for example that law enforcement data can: be a valuable source for both top-down, large-scale statistical analyses and nuanced, bottom-up enquiries; underpin evaluations, a particularly neglected area in trafficking research; and help redress the longstanding neglect of offenders and the offending process in the literature. Working with law enforcement data can be challenging in practice and it is vital to maintain independence and integrity throughout the research process. Based on the authors' experiences both sides of the academia-law enforcement divide, key areas to consider include: initial design and contact; appreciating resource issues; gaining organisational support; dealing with sensitive and restricted data; and managing dissemination. It is hoped that this chapter will stimulate increased interest in law enforcement data as a source for academic research on human trafficking. 


\section{Acknowledgements}

The following agencies' invaluable contributions to the research in the case studies are gratefully acknowledged: Bedfordshire Constabulary; Derbyshire Constabulary; Gloucestershire Constabulary; Greater Manchester Police; Hampshire Constabulary; Lancashire Constabulary; South Yorkshire Police; West Mercia Police; Her Majesty's Courts and Tribunal Service; and the National Crime Agency. We are also grateful to our section editor, Masja van Meeteren, for her insightful comments on an earlier draft. Our final thanks go to the studies' funders: the Engineering and Physical Research Council (EPSRC) and the Economic and Social Research Council (ESRC). This chapter was written under Ella Cockbain's ESRC Future Research Leaders Fellowship (grant reference: ES/K008463/1).

\section{References}

Andrees B, van der Linden MNJ (2005) Designing Trafficking Research from a Labour Market Perspective: The ILO Experience1 International Migration 43:55-73

Aronowitz AA (2001) Smuggling and trafficking in human beings: the phenomenon, the markets that drive it and the organisations that promote it European Journal on Criminal Policy and Research 9:163-195

Aronowitz AA (2009) Human trafficking, human misery: the global trade in human beings. Global Crime and Justice. The Scarecrow Press, Plymouth

Bjelland HF, Dahl JY (2017) Exploring Criminal Investigation Practices: The Benefits of Analysing Police-Generated Investigation Data European Journal of Policing Studies 
Brayley H, Cockbain E, Laycock G (2011) The value of crime scripting: Deconstructing internal child sex trafficking Policing 5:132-143

Bullock K, Clarke RV, Tilley N (2010) Introduction. In: Bullock K, Clarke RV, Tilley N (eds) Situational Prevention of Organised Crimes. Crime Science Series, First edn. Willan, Cullompton, pp 1-16

Bullock K, Tilley N (2009) Evidence-based policing and crime reduction Policing: A journal of policy and practice 3:381387

Campana P (2016) The structure of human trafficking: lifting the bonnet on a nigerian transnational network British Journal of Criminology 56:68-86

Canter D (2004) A tale of two cultures: A comparison of the cultures of the police and of academia. In: Villiers $P$, Adlam R (eds) Policing a Safe, Just and Tolerant Society: An International Model. Waterside Press, Winchester, pp 109-121

Clark T (2008) We're Over-Researched Here!' Exploring Accounts of Research Fatigue within Qualitative Research Engagements Sociology 42:953-970

Cockbain E (2013a) Grooming and the 'Asian sex gang predator': the construction of a racial crime threat Race \& Class 54:22-32 doi:10.1177/0306396813475983

Cockbain E (2013b) The trafficking of British children within the UK for sexual exploitation: A situational analysis. University College London (University of London)

Cockbain E (2015) Getting a foot in the closed door: Practical advice for starting out in research into crime and policing issues. In: Cockbain E, Knutsson J (eds) Applied Police Research: Challenges and Opportunities. Routledge, Abingdon, pp 21-33

Cockbain E (2018) Offender and Victim Networks in Human Trafficking. Routledge, Abingdon 
Cockbain E, Ashby M, Brayley-Morris H (2016) Children, gender and sexual exploitation: A quantitative analysis of adminstrative data SAGE Research Methods Cases 2:1-17 doi:http://dx.doi.org/10.4135/9781473993341

Cockbain E, Bowers K, Dmitrova G (2018) Human trafficking for labour exploitation: the resuts of a two-phase systematic review mapping the European evidence base and synthesising key scientific research evidence Journal of Experimental Criminology

Cockbain E, Brayley H, Laycock G (2011) Exploring internal child sex trafficking networks using social network analysis Policing 5:144-157

Cockbain E, Brayley-Morris H (2017) Human trafficking and labour exploitation in the casual construction industry: An analysis of three major investigations in the United Kingdom involving Irish Traveller offending groups Policing: A Journal Of Policy And Practice

Cockbain E, Knutsson J (2015a) Applied Police Research:

Challenges and Opportunities vol 16. Routledge, Cockbain E, Knutsson J (2015b) Introduction. In: Cockbain E, Knutsson J (eds) Applied Police Research: Challenges and Opportunities. Routledge, Abingdone, pp 1-8

Cockbain E, Wortley R (2015) Everyday atrocities: does internal (domestic) sex trafficking of British children satisfy the expectations of opportunity theories of crime? Crime Science 4:1-12

Dandurand $Y$ (2017) Human trafficking and police governance Police Practice and Research 18:322-336

De Angelis MI (2012) Human Trafficking: Women's Stories of Agency. University of Hull

Denton E (2016) Anatomy of offending: Human trafficking in the United States, 2006-2011 Journal of Human Trafficking 2:32-62 
Di Nicola A (2007) Researching into human trafficking: Issues and problems. In: Lee $M($ ed) Human Trafficking. Willan, Cullompton, pp 49-72

Efrat A (2016) Global efforts against human trafficking: The misguided conflation of sex, labor, and organ trafficking International Studies Perspectives 17:34-54

Farrell A (2014) Environmental and institutional influences on police agency responses to human trafficking Police Quarterly 17:3-29

Farrell A, McDevitt J, Pfeffer R, Fahy S, Owens C, Dank M, Adams W (2012) Identifying Challenges to Improve the Investigation and Prosecution of State and Local Human Trafficking Cases. Northeastern University, Boston, MA

Farrell A, Owens C, McDevitt J (2014) New laws but few cases:

Understanding the challenges to the investigation and prosecution of human trafficking cases Crime, Law and Social Change 61:139-168

Farrell A, Pfeffer R (2014) Policing human trafficking: Cultural blinders and organizational barriers The Annals of the American Academy of Political and Social Science 653:4664

Feingold D (2010) Trafficking in Numbers: The Social Construction of Human Trafficking Data. In: Andreas P, Greenhill K (eds) Sex, Drugs and Body Counts: The Politics of Numbers in Global Crime and Conflict. Cornell University Press, New York, pp 46-74

Fleming J (2010) Learning to work together: police and academics Policing: A Journal of Policy and Practice 4:139145

Foster J, Bailey S (2010) Joining forces: maximizing ways of making a difference in policing Policing: A Journal of Policy and Practice 4:95-103

Gadd D, Broad R, Craven J, Lightowlers C, Bellotti E (2017) Mapping the Contours of Modern Slavery in Greater Manchester. University of Manchester, Manchester 
Gavra D, Tudor D Addressing the Problem: Institutional Factors that Facilitate Human Trafficking and Potential Preventative Measures through Communication. In: Redefining Community in Intercultural Context ( $\mathrm{RCIC})$ 2015, Brasov, 2015.

Goodey J (2008) Human trafficking Sketchy data and policy responses Criminology and Criminal Justice 8:421-442 Gozdziak E, Collett E (2005) Research on Human Trafficking in North America: A Review of Literature International Migration 43:99-128

Helfferich C, Kavemann B, Rabe H (2011) Determinants of the willingness to make a statement of victims of human trafficking for the purpose of sexual exploitation in the triangle offender-police-victim Trends in organized crime $14: 125$

Hopper E, Hidalgo J (2006) Invisible chains: Psychological coercion of human trafficking victims Intercultural Hum Rts L Rev 1:185

Information Commissioner's Office (2018) Guide to the General Data Protection Regulation (GDPR). Information Commissioner's Office Wilmslow International Organization for Migration (2001) Victims of

Trafficking in the Balkans: A Study of Trafficking in Women and Chil-

dren for Sexual Exploitation to, through and from the Balkan Region, IOM, Geneva. IOM, Geneva Johnson SD, Tilley N, Bowers KJ (2015) Introducing EMMIE: an evidence rating scale to encourage mixed-method crime prevention synthesis reviews Journal of Experimental Criminology 11:459-473 doi:10.1007/s11292-015-9238-7 Jokinen A, Ollus N, Joutsen M (eds) (2013) Exploitation of migrant workers in Finland, Sweden, Estonia and Lithuania: uncovering the links between recruitment, 
irregular employment practices and labour trafficking. HEUNI, Helsinki

Kelly L (2002) Journeys of Jeopardy: A Review of Research on

Trafficking in Women and Children in Europe.

International Organization for Migration, Geneva

Kelly L (2005) "You can find anything you want": A critical

reflection on research on trafficking in persons within and into Europe International Migration 43:235-265

Kennedy DM (2015) Working in the field: Police research in theory and in practice. In: Cockbain E, Knutsson J (eds) Applied police research: Challenges and opportunities. Routledge, Abingdon, pp 9-20

Kleemans ER (2011) Expanding the domain of human trafficking research: introduction to the special issue on human trafficking Trends in organized crime 14:95-99

Kleemans ER (2015) Organized Crime Research: Challenging assumptions and informing policy. In: Cockbain E, Knutsson J (eds) Applied Police Research: Challenges and Opportunities. Routledge, Abingdon, pp 57-67

Kragten-Heerdink SL, Dettmeijer-Vermeulen CE, Korf DJ (2017) More Than Just "Pushing and Pulling": Conceptualizing Identified Human Trafficking in the Netherlands Crime \& Delinquency:0011128717728503

Laczko F (2005) Data and research on human trafficking International Migration 43:5-16

Laczko F, Gozdziak E (2005) Data and Research on Human Trafficking: A Global Survey. International Organization for Migration, Geneva

Laczko F, Gramegna MA (2003) Developing better indicators of human trafficking The Brown Journal of world affairs 10:179-194

Legerski J-P, Bunnell SL (2010) The risks, benefits, and ethics of trauma-focused research participation Ethics \& Behavior 20:429-442 
Lehti M, Aromaa K (2006) Trafficking for Sexual Exploitation

Crime and Justice 34:133-227 doi:10.1086/650306

Madensen T, Sousa W (2015) Practical academics: Positive

outcomes of police-researcher collaborations. In:

Cockbain E, Knutsson J (eds) Applied Police Research:

Challenges and Opportunities. Routledge, Abingdon, pp 68-81

Mancuso M (2014) Not all madams have a central role: analysis of a Nigerian sex trafficking network Trends in Organized Crime 17:66-88

Maxfield M, Babbie E (eds) (2011) Research Methods for

Criminal Justice and Criminology. Sixth edition edn.

Wadsworth, Belmont

Maxfield M, Babbie E (2014) Research Methods for Criminal

Justice and Criminology. 7th edn. Wadsworth, Belmont

Mayhew P (2016) In defence of administrative criminology

Crime Science 5:7

Noaks L, Wincup E (2004) Criminological Research:

Understanding Qualitative Methods. Sage, London

Oram S, Ostrovschi NV, Gorceag VI, Hotineanu MA, Gorceag L,

Trigub C, Abas M (2012) Physical health symptoms

reported by trafficked women receiving post-trafficking

support in Moldova: prevalence, severity and associated

factors BMC Women's Health 12:1-9

Parmentier S (2010) Epilogue: Human trafficking seen from the

future European Journal of Criminology 7:95-100

Pawson R, Tilley N (1997) Realistic evaluation. Sage, London

Perez DW, Shtull PR (2002) Police research and practice: an

American perspective Police Practice and Research 3:169187

Raymond J, Hughes DM (2001) Sex Trafficking of Women in the United States: International and Domestic Trands.

Savona E, Giommoni L, Mancuso M (2014) Human trafficking for sexual exploitation in Italy. In: Leclerc B, Wortley $R$ 
(eds) Cognition and crime: Offending decision making and script analysis. Routledge, Abingdon, pp 140-163

Sheptycki J (2004) Organizational pathologies in police

intelligence systems: Some contributions to the lexicon of intelligence-led policing European Journal of Criminology $1: 307-332$

Silverman B (2014) Modern Slavery: an application of Multiple Systems Estimation. Home Office,, London Sparrow M (2011) Governing Science: New Perspectives in Policing Washington: Harvard Kennedy School, National Institute of Justice

Tamas A, Moise A, Predut C, Medvichi N (2013) Trafficking in

Persons for Begging- Romania Study. Schweizerische Eidgenossenschaft and ANITP, Publication location not stated

Tilley N (2006) Knowing and Doing: Guidance and Good Practice in Crime Prevention. In: Knutsson J, Clarke RV (eds) Putting Theory to Work: Implementing Situational Prevention and Problem-Oriented Policing, vol 20. Crime Prevention Studies. Criminal Justice Press, Monsey, NY, pp 217-252

TNS OBOP and the British Embassy Warsaw (2010) Public awareness of risks involved in human trafficking and taking up work abroad. TNS OBOP, Publication location not stated

Turner-Moss E, Zimmerman C, Howard LM, Oram S (2014) Labour Exploitation and Health: A Case Series of Men and Women Seeking Post-Trafficking Services Journal of Immigrant and Minority Health 16:473-480

Tyldum G (2010) Limitations in research on human trafficking International Migration 48:1-13

Tyldum G, Brunovskis A (2005) Describing the unobserved:

Methodological challenges in empirical studies on human trafficking International Migration 43:17-34 doi:10.1111/j.0020-7985.2005.00310.x 
Van Der Laan P, Smit M, Busschers I, Aarten P (2011) Crossborder trafficking in human beings: Prevention and intervention strategies for reducing sexual exploitation: A Systematic Review Campbell Systematic Reviews 7

Webb EJ, Campbell DT, Schwartz RD, Sechrest L (1966)

Unobtrusive Measures: Non-reactive Research in the Social Sciences. Rand McNally, Chicago

Winterdyk J, Reichel P (2010) Introduction to Special Issue:

Human Trafficking Issues and Perspectives European Journal of Criminology 7:5-10

Zimmerman C, Hossain M, Yun K, Roche B, Morison L, Watts C (2006) Stolen smiles: a summary report on the physical and psychological health consequences of women and adolescents trafficked in Europe. London School of Hygiene and Tropical Medicine, London 